This PDF is a selection from an out-of-print volume from the National Bureau of Economic Research

Volume Title: Issues in the Economics of Aging

Volume Author/Editor: David A. Wise, editor

Volume Publisher: University of Chicago Press, 1990

Volume ISBN: 0-226-90297-8

Volume URL: http://www.nber.org/books/wise90-1

Conference Date: May 19-21, 1988

Publication Date: January 1990

Chapter Title: The Joint Retirement Decision of Husbands and Wives

Chapter Author: Michael D. Hurd

Chapter URL: http://www.nber.org/chapters/c7119

Chapter pages in book: (p. 231 - 258) 


\title{
The Joint Retirement Decision of Husbands and Wives
}

\author{
Michael D. Hurd
}

Whereas the retirement behavior of males has been rather intensively studied, very little attention has been paid to the retirement behavior of couples, most likely because in a self-weighting sample there are not many observations on working women of retirement age (for the retirement behavior of males, see Boskin and Hurd 1978; Burkhauser 1980; Mitchell and Fields 1983, 1984; Diamond and Hausman 1984; Hurd and Boskin 1984; Burtless and Moffitt 1985; Hausman and Wise 1985; Honig and Hanoch 1985; Gustman and Steinmeier 1986; and Sickles and Taubman 1986). For example, Pozzebon and Mitchell (1989) use just 139 observations from the Retirement History Survey (RHS) to study the retirement behavior of married women. Because the labor force participation rate of women has grown substantially over the last thirty years, the retirement behavior of women will become increasingly important in understanding many issues such as the future size of the labor force, the number of retirees, and the aggregate cost of Social Security benefits. Of particular interest is the joint retirement behavior of husband and wife, both because numerically couples of retirement age are more important than single people of retirement age and because the joint retirement decision is much more complex than the decision of an individual.

Most research on the retirement of males finds that the date of retirement is affected by the level of Social Security benefits, health, mandatory retirement, and, to a lesser extent, other aspects of the economic environment such as the wage rate and assets. For example, Hurd and Boskin (1984) find that the increase in Social Security benefits during the early 1970s provided a good

Michael D. Hurd is professor of economics at the State University of New York, Stony Brook, and a research associate of the National Bureau of Economic Research.

Support from the Social Security Administration under grant 10-P-98298-1-01 to the NBER is gratefully acknowledged. Many thanks to Tai Hsin Huang for excellent research assistance. 
explanation for the decline in elderly male labor force participation during that period. They further find that bad health has a strong effect toward early retirement and that mandatory retirement at age 65 approximately doubles the probability of complete retirement at age 65 . (The individual retires rather than finding another job.) Hausman and Wise (1985) obtain similar findings. This line of research generally considers only husbands whose wives are not working, so the issue of the joint choice of retirement dates does not arise. Studies of family labor supply, however, typically find that the wife's labor supply is influenced by the husband's wage rate or by the husband's income. It would not be surprising, therefore, to find that the wife's retirement date is influenced by the variables that help determine the husband's retirement date. Whether the husband's retirement date is similarly influenced by the wife's variables is more of an open question.

Although a correlation between husbands' and wives' retirement dates has yet to be firmly established, there are several kinds of reasons why one might expect to find such a correlation. ${ }^{1}$ If men who have a particularly strong taste for goods marry women with similar tastes, one would find a positive correlation between retirement dates, even if retirement dates are not influenced by any economic variables. A correlation could also be caused by economic variables: for example, both the husbands and the wives in families with substantial assets may tend to retire early, which would induce a positive correlation in dates. A more interesting example is correlation caused by cross-wage effects. Cross-wage effects could be due to income effects on the retirement dates of both husband and wife and/or to compensated cross-wage effects. The compensated effects result from a utility function in which the own marginal rate of substitution of goods for leisure is affected by the leisure of the spouse. One might well imagine such an effect particularly with respect to years of retirement: own retirement years may be less pleasurable if the spouse is working because of constraints put on traveling and so forth. This kind of reasoning would suggest that husbands' and wives' years of retirement are compliments, so that, ceteris paribus, they would desire to retire at the same time.

This paper has two goals. The first is to give some empirical evidence on the correlation between retirement dates. Do husbands and wives in fact tend to retire at the same time, and how strong is the tendency? The results should provide a baseline for future research. The second goal is to find, within the constraints of the data, whether observable economic variables contribute to any correlation in retirement dates and to find evidence of compensated cross-equation effects.

The data set is the New Beneficiary Survey (NBS). It has the advantage of a substantial number of observations on working husbands and wives of retirement age. Its main disadvantage is that it is a choice-based cross section, which limits the complexity of the analysis that can be undertaken. 
The main findings are that husbands and wives tend to retire at the same time. Some of the results can be interpreted to mean that their retirement years are compliments. There is weaker evidence that some of each spouse's economic variables influence the retirement age of the other, but the findings are not robust enough to attempt to find compensated effects.

\subsection{Data}

The NBS is a survey of individuals who first received social security benefits in the "window," June 1980-May 1981 (Maxfield 1983). The individuals and their spouses were interviewed in October-December 1982. Nine categories of recipients were defined. For this study, the important ones are retired male workers and retired female workers. A retired male worker received his first retirement benefits during the window and was entitled on his own earnings record, and similarly for retired female workers. A number of the female workers, in particular, were dually entitled. Within each category, sampling rates varied by the age of the recipient. The sample sizes and sampling rates are given in table 8.1.

Although the NBS is a choice-based sample, in a static population it can be used for analysis, provided the proper weighting is used. For example, suppose that one wanted to find the probability that an eligible 62-year-old would receive his first benefits at age 63 . This is a conditional probability, conditioned on his not having previously received benefits. It is also called the hazard rate or risk of receiving initial benefits at 63 . In a static population, the hazard would be the number of 63 -year-olds in the NBS divided by the number greater than 62 , all weighted by the inverse of the sampling rate. Even though one does not observe the actual population of 63-year-olds exposed to the risk of benefit receipt, that population can be estimated from the fractions of older vintages that reached 63 without having received benefits. However, in a dynamic

Table 8.1

\begin{tabular}{ccc}
\hline & Sample Size & Sampling Rate \\
\hline Male workers: & & \\
62 & 1,442 & $1 / 213$ \\
$63-64$ & 1,466 & $1 / 115$ \\
65 & 1,388 & $1 / 67$ \\
$66+$ & 1,011 & $1 / 53$ \\
Female workers: & & \\
62 & 1,319 & $1 / 236$ \\
$63-64$ & 1,074 & $1 / 95$ \\
65 & 1,045 & $1 / 50$ \\
$66+$ & 774 & $1 / 24$ \\
\hline
\end{tabular}


population this calculation loses accuracy because the population of 63-yearolds at risk is not the sum of the older recipients. For example, if the population were growing, the population at risk would be underestimated, so the risk would be overestimated. Similar reasoning applies to the estimation of the response of retirement age to economic variables. For example, suppose one wants to find how the wage affects the probability of retirement at 63 . In a static population, one observes the entire distribution of wages and retirement dates, so that, in principle, the desired parameter could be estimated. If wages are growing over time, however, the older recipients in the NBS come from cohorts that had lower wages when they were 63 than the current 63 -year-old recipients. One would associate low wages with late retirement. Even if the wage had no effect on retirement, one would estimate that the retirement hazard at 63 increases with the wage.

In the NBS, the respondents and their spouses were asked extensive questions about their work histories, incomes, assets, wages, and health condition. From the answers, one can construct their economic environment at the time of the interview, but not in the years before the interview. This limits the complexity of the retirement model that can be estimated with the NBS because one does not know the alternatives that caused them to continue to work in earlier years. This is a weakness of the NBS compared with other data sets such as the RHS. The strength of the NBS is that it has a generous number of observations on recently retired husbands and wives.

\subsection{Data Analysis}

The goal of this section is to present evidence on whether husbands and wives tend to retire at the same time. No economic variables will be taken into account, so the results will simply establish the kinds of behavior that have to be explained by a model.

In these data, someone is said to be retired when he or she is not working. In that all respondents are at least 63 years old by the time of the survey and have received retired workers' Social Security benefits, there is probably little unretirement. For the results of this section, the sample is restricted to couples in which both the husband and the wife have a date of leaving the last job. This eliminates couples in which the wife worked only when she was young because only jobs held after 1950 are recorded. For most of the results, the sample will be further restricted to include only couples in which both retired after the age of 54 , so that the behavior accords more with what is generally taken to be retirement.

In the male-worker sample, 1,536 couples satisfied these requirements and several other minor requirements concerning missing data. The median difference between the husband's and the wife's retirement dates is about 3.8 years. In that the average age difference is about 3.1 years, this implies that many husbands and wives retire at about the same age. Table 8.2 gives the 
Table 8.2

Distribution of the Difference in Retirement Dates

\begin{tabular}{|c|c|c|c|c|c|c|c|}
\hline \multirow{2}{*}{$\begin{array}{l}\text { Difference in } \\
\text { Retirement Dates }\end{array}$} & \multicolumn{7}{|c|}{ Husband's Retirement Age ${ }^{a}$} \\
\hline & $55-59$ & $60-61$ & 62 & $63-64$ & 65 & $66+$ & All \\
\hline Same month & 9.0 & 12.0 & 5.8 & 5.8 & 4.2 & 5.4 & 6.1 \\
\hline One month & 9.0 & 14.8 & 6.3 & 10.5 & 7.1 & 8.5 & 9.4 \\
\hline Two months & 9.0 & 15.5 & 9.5 & 12.1 & 9.9 & 10.1 & 11.0 \\
\hline Same year & 19.2 & 32.4 & 23.6 & 26.7 & 25.3 & 20.5 & 24.6 \\
\hline More than one year & 80.8 & 67.6 & 76.4 & 73.3 & 74.4 & 79.5 & 75.4 \\
\hline \multirow[t]{3}{*}{ Observations } & 78 & 142 & 190 & 397 & 355 & 386 & 1,548 \\
\hline & \multicolumn{7}{|c|}{ Wife's Retirement Age ${ }^{\mathrm{b}}$} \\
\hline & $55-59$ & $60-61$ & 62 & $63-64$ & 65 & $66+$ & All \\
\hline Same month & 8.9 & 6.1 & 10.4 & 8.1 & 6.1 & 11.9 & 8.5 \\
\hline One month & 11.5 & 10.6 & 14.0 & 11.0 & 8.5 & 14.5 & 11.5 \\
\hline Two months & 12.7 & 12.9 & 14.8 & 13.3 & 10.9 & 16.4 & 13.8 \\
\hline Same year & 28.0 & 27.2 & 33.0 & 28.3 & 25.4 & 27.7 & 28.1 \\
\hline More than one year & 72.7 & 72.8 & 67.0 & 71.7 & 74.6 & 72.3 & 71.9 \\
\hline Observations & 157 & 132 & 115 & 173 & 165 & 159 & 901 \\
\hline
\end{tabular}

Source: Author's calculations from the NBS.

Note: Entries are percentage of each column.

${ }^{a}$ Based on male-workers sample.

${ }^{\mathrm{b}}$ Based on female-workers sample.

distribution of the difference between the husband's and the wife's retirement dates. In the male-workers sample, 6.1 percent of couples retired in the same month; 9.4 percent within one month of each other; 11.0 percent within two months of each other; and 24.6 percent in the same year. In the female-workers sample, even greater coordination of retirement dates is found: 8.5 percent retired within the same month. Although it is not shown in the table, no other concentration of the difference in retirement dates appears. That is, the distribution is flat everywhere except at differences of a year or less, where there is substantial mass. The table certainly suggests joint determination of retirement dates.

To find if the coordination of retirement dates could be induced by the Social Security system, the distribution was calculated by the retirement age of the respondent. The idea is that Social Security has different effects at different ages, so the amount of coordination of retirement dates should vary by age. For example, if eligibility for benefits at age 62 causes both husband and wife to retire at the same time, one would expect a greater concentration of the distribution among respondents who retire at 62 than among respondents who retire at 63 or 64 . The table has some suggestion of such an effect in the female-workers sample, but it is not verified in the male-workers sample. In fact, no pattern is apparent in both data sets. The table does not distinguish 
coordination of retirement due to economic variables from coordination caused by complimentarity in leisure; but the table would appear to rule out coordination caused by assortative mating because, while assortative mating would induce a correlation between retirement dates, it would not cause such high concentrations within a year.

The remainder of this section will be devoted to other ways of studying the correlation in retirement dates that is suggested by the findings in table 8.2. The idea that husbands and wives desire to retire at the same time will be called the joint retirement hypothesis.

Table 8.3 shows the probability in the male-workers sample that the wife retires in a particular age interval as a function of the husband's age at retirement and of the difference in their ages. For example, among husbands who retire at age 62 and who are the same age as their wives, 30 percent have wives who retire between 55 and 59. This number is calculated from the relevant subsample of the male-workers sample by taking the ratio of the number of wives who retire at 55-59 divided by the total number of husbands who retire at 62 . The average is unweighted because the conditioning event means that approximately all the observations in a column receive the same weight. Many of the entries in the table are missing because of sample selection: having selected on husband's retirement age and age difference, one cannot observe the fraction of wives that retire at certain ages. Consider, for example, husbands who retired at 62 and are three years older than their wives. At the time of the survey, most of the husbands were 63 ; their wives were 60 , and some of the wives were still working. One does not know how many will retire at 62 . The table does not extend beyond age differences of four and minus one because the number of observations becomes small.

If the joint retirement hypothesis is correct, the wife's retirement probability will vary with the age difference: the wife's retirement probability should be greatest at the age difference when both husband and wife can retire at the same time. An example is when the husband's retirement age is 62 and the wife's retirement age is 55-59. When the age difference is two, the wife is 60 at the husband's retirement; when the difference is three, she is 59. One would expect, therefore, the probability the wife retires at 59 to be greater when the age difference is three than when the age difference is two, and the table shows that to be the case. A counterexample is when the husband's retirement is 65 , the wife's retirement is 63-64, and the age differences are zero and one. One would expect a higher retirement probability to be associated with the greater age difference, but that is not the case. Only a few similar comparisons can reliably be made because of missing data or small samples. If one restricts comparisons to cells in which the husband and wife retire at the same time and cells adjacent to those, just five comparisons in which the probabilities are based on more than fifteen observations can be made. Table 8.4 is an extract of table 8.3; it has comparisons that are based on ten or more observations. The 
Table 8.3

Probability Wife Retires

\begin{tabular}{|c|c|c|c|c|c|c|c|}
\hline \multirow{2}{*}{$\begin{array}{l}\text { Wife's } \\
\text { Retirement Age }\end{array}$} & \multirow{2}{*}{$\begin{array}{c}\text { Age } \\
\text { Difference }\end{array}$} & \multicolumn{6}{|c|}{ Husband's Retirement Age } \\
\hline & & $55-59$ & $60-61$ & 62 & $63-64$ & 65 & $66+$ \\
\hline \multirow[t]{6}{*}{$55-59$} & 4 & - & - & - & .31 & .04 & .19 \\
\hline & 3 & b & .30 & .41 & .27 & .14 & .21 \\
\hline & 2 & .33 & .37 & .35 & .26 & .14 & .19 \\
\hline & 1 & $\mathbf{b}$ & $.17^{\mathrm{a}}$ & .15 & .29 & .25 & .11 \\
\hline & 0 & b & $.14^{\mathrm{a}}$ & $.30^{\mathrm{a}}$ & .36 & .20 & .22 \\
\hline & -1 & b & $.20^{\mathrm{a}}$ & $.13^{\mathrm{a}}$ & .09 & $.23^{\mathrm{a}}$ & $.33^{\mathrm{a}}$ \\
\hline \multirow[t]{6}{*}{$60-61$} & 4 & - & - & - & - & .17 & .13 \\
\hline & 3 & - & - & - & - & .10 & .15 \\
\hline & 2 & - & - & - & - & .12 & .06 \\
\hline & 1 & b & $.50^{\mathrm{a}}$ & .26 & .10 & .19 & .14 \\
\hline & 0 & b & $.36^{\mathrm{a}}$ & $.30^{\mathrm{a}}$ & .12 & .07 & .09 \\
\hline & -1 & $\mathrm{~b}$ & $.30^{\mathrm{a}}$ & $.33^{\mathrm{a}}$ & .18 & $.08^{\mathrm{a}}$ & $.08^{\mathrm{a}}$ \\
\hline \multirow[t]{6}{*}{62} & 4 & - & - & - & - & - & .16 \\
\hline & 3 & - & - & - & - & .14 & .17 \\
\hline & 2 & - & - & - & - & .12 & .04 \\
\hline & 1 & - & - & - & - & .16 & .11 \\
\hline & 0 & b & $.14^{a}$ & $.10^{\mathrm{a}}$ & .06 & .07 & .09 \\
\hline & -1 & b & $.20^{\mathrm{a}}$ & $.20^{\mathrm{a}}$ & .00 & $.08^{\mathrm{a}}$ & $.08^{\mathrm{a}}$ \\
\hline \multirow[t]{6}{*}{$63-64$} & 4 & - & - & - & - & - & - \\
\hline & 3 & - & - & - & - & - & - \\
\hline & 2 & - & - & - & - & - & - \\
\hline & 1 & - & - & - & - & .22 & .17 \\
\hline & 0 & - & - & - & - & .27 & .30 \\
\hline & -1 & - & - & - & - & $.23^{\mathrm{a}}$ & $.25^{\mathrm{a}}$ \\
\hline \multirow[t]{6}{*}{65} & 4 & - & - & - & - & - & - \\
\hline & 3 & - & - & - & - & - & - \\
\hline & 2 & - & - & - & - & - & - \\
\hline & 1 & - & - & - & - & - & .11 \\
\hline & 0 & - & - & - & - & .23 & .04 \\
\hline & -1 & - & - & - & - & $.00^{\mathrm{a}}$ & $.17^{\mathrm{a}}$ \\
\hline \multirow[t]{6}{*}{$66+$} & 4 & - & - & - & - & - & - \\
\hline & 3 & - & - & - & - & - & - \\
\hline & 2 & - & - & - & - & - & - \\
\hline & 1 & - & - & - & - & - & .34 \\
\hline & 0 & - & - & - & - & .17 & .26 \\
\hline & -1 & - & - & - & - & $.15^{\mathrm{a}}$ & $.00^{\mathrm{a}}$ \\
\hline
\end{tabular}

Source: Author's calculations from the NBS.

Note: Based on male-workers sample. Age difference is husband's age minus wife's age. "." means the probability is not reliably observed.

${ }^{a}$ Based on ten to fifteen observations.

${ }^{b}$ Based on fewer than ten observations. 
Table 8.4 Comparison of Retirement Probabilities

\begin{tabular}{|c|c|c|c|c|}
\hline $\begin{array}{l}\text { Husband's } \\
\text { Retirement Age }\end{array}$ & $\begin{array}{c}\text { Wife's } \\
\text { Retirement Age }\end{array}$ & $\begin{array}{c}\text { Age } \\
\text { Difference }\end{array}$ & $\begin{array}{l}\text { Retirement } \\
\text { Probability }\end{array}$ & Supports \\
\hline \multirow[t]{2}{*}{$60-61$} & $55-59$ & 1 & $.17^{\mathrm{a}}$ & Yes \\
\hline & & 0 & $.14^{\mathrm{a}}$ & \\
\hline \multirow[t]{2}{*}{62} & $55-59$ & 3 & .41 & Yes \\
\hline & & 2 & .35 & \\
\hline \multirow[t]{2}{*}{62} & $60-61$ & 1 & .26 & No \\
\hline & & 0 & $.30^{\mathrm{a}}$ & \\
\hline \multirow[t]{2}{*}{62} & 62 & 0 & $.10^{\mathrm{a}}$ & No \\
\hline & & -1 & $.20^{\mathrm{a}}$ & \\
\hline \multirow[t]{2}{*}{65} & $60-61$ & 4 & .17 & Yes \\
\hline & & 3 & .10 & \\
\hline \multirow[t]{2}{*}{65} & 62 & 3 & .14 & Yes \\
\hline & & 2 & .12 & \\
\hline \multirow[t]{2}{*}{65} & $63-64$ & 1 & .22 & No \\
\hline & & 0 & .27 & \\
\hline \multirow[t]{2}{*}{65} & 65 & 0 & .23 & Yes \\
\hline & & -1 & $.00^{a}$ & \\
\hline \multirow[t]{2}{*}{$66+$} & 65 & 1 & .11 & Yes \\
\hline & & 0 & .04 & \\
\hline
\end{tabular}

Source: Table 8.3 .

${ }^{a}$ Based on ten to fifteen observations.

last column indicates whether the comparison supports the joint retirement hypothesis: six of the nine entries show support.

Table 8.5 has the probability the husband retires classified by the age at which the wife retires and by the age difference; the probabilities are based on the female-workers data. Seven comparisons of retirement probabilities similar to those in table 8.4 can be made; six support the joint retirement hypothesis. In total, then, twelve of sixteen comparisons support the hypothesis. The fraction of successful comparisons is different from $1 / 2$ at about the .05 significance level.

These kinds of comparisons are not very systematic, and some subjective judgment is exercised in choosing the cases. Furthermore, one would think that age differences would shift the entire distribution of retirement ages, which would change the retirement probabilities at every age. For example husbands who are four years older than their wives should be less likely to retire at younger ages than husbands who are the same age as their wives.

Because husbands tend to be older than their wives, many of the retirement probabilities are not reliable in the male-worker data. The rest of the data analysis, therefore, uses only the female-workers sample. The object of analysis is the distribution of the husband's retirement age conditional on the retirement age of the wife. The joint retirement hypothesis implies that as the age difference increases the probability that the husband retires at an early age 
Table 8.5

Probability Husband Retires

\begin{tabular}{|c|c|c|c|c|c|c|c|}
\hline \multirow{2}{*}{$\begin{array}{l}\text { Husband's } \\
\text { Retirement Age }\end{array}$} & \multirow{2}{*}{$\begin{array}{c}\text { Age } \\
\text { Difference }\end{array}$} & \multicolumn{6}{|c|}{ Wife's Retirement Age } \\
\hline & & $55-59$ & $60-61$ & 62 & $63-64$ & 65 & $66+$ \\
\hline \multirow[t]{6}{*}{$55-59$} & 4 & .09 & .00 & $.15^{\mathrm{a}}$ & $.00^{\mathrm{a}}$ & .06 & .16 \\
\hline & 3 & .25 & $.15^{\mathrm{u}}$ & .06 & .07 & .09 & $.09^{\mathrm{a}}$ \\
\hline & 2 & $.20^{\mathrm{a}}$ & .06 & .06 & .19 & .12 & $.00^{\mathrm{a}}$ \\
\hline & 1 & .22 & .20 & $.21^{\mathrm{a}}$ & .06 & $.14^{\mathrm{a}}$ & .08 \\
\hline & 0 & .29 & $.09^{\mathrm{a}}$ & .11 & .10 & .00 & .06 \\
\hline & -1 & $.00^{\mathrm{a}}$ & $.30^{\mathrm{a}}$ & $.00^{\mathrm{b}}$ & $.08^{\mathrm{a}}$ & $.13^{a}$ & $.13^{\mathrm{a}}$ \\
\hline \multirow[t]{6}{*}{$60-61$} & 4 & .09 & .15 & $.23^{\mathrm{a}}$ & $.00^{\mathrm{a}}$ & .06 & .05 \\
\hline & 3 & .10 & $.15^{\mathrm{a}}$ & .06 & .15 & .05 & $.00^{\mathrm{a}}$ \\
\hline & 2 & $.00^{\mathrm{a}}$ & .13 & .06 & .07 & .04 & $.13^{\mathrm{a}}$ \\
\hline & 1 & .11 & .10 & $.00^{\mathrm{a}}$ & .03 & $.29^{\mathrm{a}}$ & .08 \\
\hline & 0 & .12 & $.27^{\mathrm{a}}$ & .22 & .00 & .17 & .00 \\
\hline & -1 & $.23^{\mathrm{a}}$ & $.20^{\mathrm{a}}$ & $.20^{\mathrm{b}}$ & $.15^{\mathrm{a}}$ & $.07^{\mathrm{a}}$ & $.00^{\mathrm{a}}$ \\
\hline \multirow[t]{6}{*}{62} & 4 & .18 & .10 & $.08^{\mathrm{a}}$ & $.00^{\mathrm{a}}$ & .00 & .00 \\
\hline & 3 & .15 & $.08^{\mathrm{a}}$ & .00 & .07 & .14 & $.27^{\mathrm{a}}$ \\
\hline & 2 & $.13^{\mathbf{a}}$ & .19 & .17 & .00 & .12 & $.13^{\mathrm{a}}$ \\
\hline & 1 & .11 & .25 & $.07^{\mathrm{a}}$ & .13 & $.00^{\mathrm{a}}$ & .00 \\
\hline & 0 & .00 & $.09^{\mathrm{a}}$ & .33 & .00 & .06 & .11 \\
\hline & -1 & - & - & - & $.15^{\mathrm{a}}$ & $.00^{\mathrm{a}}$ & $.13^{\mathrm{a}}$ \\
\hline \multirow[t]{6}{*}{$63-64$} & 4 & .14 & .35 & $.08^{\mathrm{a}}$ & $.09^{\mathrm{a}}$ & .18 & .11 \\
\hline & 3 & .05 & $.15^{\mathrm{a}}$ & .29 & .15 & .09 & $.18^{\mathrm{a}}$ \\
\hline & 2 & $.13^{\mathrm{a}}$ & .25 & .44 & .11 & .04 & $.13^{\mathrm{a}}$ \\
\hline & 1 & - & - & - & .13 & $.00^{\mathrm{a}}$ & .00 \\
\hline & 0 & - & - & - & - & .39 & .17 \\
\hline & -1 & - & - & - & - & $.40^{\mathrm{a}}$ & $.07^{\mathrm{a}}$ \\
\hline \multirow[t]{6}{*}{65} & 4 & .14 & .15 & $.08^{\mathrm{a}}$ & $.00^{\mathrm{a}}$ & .35 & .16 \\
\hline & 3 & .15 & $.23^{\mathrm{a}}$ & .29 & .15 & .14 & $.09^{\mathrm{a}}$ \\
\hline & 2 & - & - & - & .15 & .12 & $.07^{\mathrm{a}}$ \\
\hline & 1 & - & - & - & - & $.43^{\mathrm{a}}$ & .04 \\
\hline & 0 & - & - & - & - & .22 & .06 \\
\hline & -1 & - & - & - & - & - & $.27^{\mathrm{a}}$ \\
\hline \multirow[t]{6}{*}{$66+$} & 4 & .36 & .25 & $.38^{\mathrm{a}}$ & $.91^{\mathrm{a}}$ & .35 & .53 \\
\hline & 3 & .30 & $.23^{\mathrm{a}}$ & .29 & .41 & .50 & $.36^{\mathrm{a}}$ \\
\hline & 2 & - & - & - & .48 & .56 & $.53^{\mathrm{a}}$ \\
\hline & 1 & - & - & - & - & $.07^{\mathrm{a}}$ & .64 \\
\hline & 0 & - & - & - & - & .17 & .61 \\
\hline & -1 & - & - & - & - & - & $.40^{\mathrm{a}}$ \\
\hline
\end{tabular}

Source: Author's calculations from the NBS.

Note: Based on female-workers sample. Age difference is husband's age minus wife's age. "_"” means the probability is not reliably observed.

${ }^{a}$ Based on ten to fifteen observations.

bBased on fewer than ten observations. 
decreases; that is, the entire distribution of retirement ages shifts toward greater ages.

The retirement distributions, conditional on the wife's retirement age, are given in table 8.6. They are found by summing the retirement probabilities in table 8.5. An example where the joint retirement hypothesis is generally supported is found in the column headed 60-61 and the rows labeled 55-62. If the husband is one year younger than the wife, he would have been 59 or 60 when the wife retired; 60 percent of such husbands retired before the age

Table 8.6 Distribution of the Retirement Age of Husband

\begin{tabular}{|c|c|c|c|c|c|c|c|}
\hline \multirow{2}{*}{$\begin{array}{l}\text { Husband's } \\
\text { Retirement Age }\end{array}$} & \multirow{2}{*}{$\begin{array}{c}\text { Age } \\
\text { Difference }\end{array}$} & \multicolumn{6}{|c|}{ Wife's Retirement Age } \\
\hline & & $55-59$ & $60-61$ & 62 & $63-64$ & 65 & $66+$ \\
\hline \multirow[t]{6}{*}{$55-59$} & 4 & .09 & .00 & $.15^{\mathrm{a}}$ & $.00^{\mathrm{a}}$ & .06 & .16 \\
\hline & 3 & .25 & $.15^{\mathrm{a}}$ & .06 & .07 & .09 & $.09^{2}$ \\
\hline & 2 & $.20^{\mathrm{a}}$ & .06 & .06 & .19 & $.12^{\mathrm{a}}$ & $.00^{\mathrm{a}}$ \\
\hline & 1 & .22 & .20 & $.21^{\mathrm{s}}$ & .06 & .14 & .08 \\
\hline & 0 & .29 & $.09^{\mathrm{a}}$ & .11 & .10 & .00 & .06 \\
\hline & -1 & $.00^{\mathrm{a}}$ & .30 & $.00^{\mathrm{b}}$ & $.08^{a}$ & $.13^{\mathrm{a}}$ & $.13^{\mathrm{a}}$ \\
\hline \multirow[t]{6}{*}{$55-61$} & 4 & .18 & .15 & $.38^{\mathrm{a}}$ & $.00^{\mathrm{a}}$ & .12 & .21 \\
\hline & 3 & .35 & $.31^{\mathrm{a}}$ & .12 & .22 & .14 & $.09^{\mathrm{a}}$ \\
\hline & 2 & $.20^{\mathrm{a}}$ & .19 & .11 & .26 & $.16^{\mathrm{a}}$ & $.13^{\mathrm{a}}$ \\
\hline & 1 & .33 & .30 & $.21^{\mathrm{a}}$ & .10 & .43 & .16 \\
\hline & 0 & .41 & $.36^{\mathrm{a}}$ & .33 & .10 & .11 & .06 \\
\hline & -1 & $.23^{\mathrm{a}}$ & .50 & $.20^{\mathrm{b}}$ & $.23^{\mathrm{a}}$ & $.20^{\mathrm{a}}$ & $.13^{\mathrm{a}}$ \\
\hline \multirow[t]{6}{*}{$55-62$} & 4 & .36 & .25 & $.46^{\mathrm{a}}$ & $.00^{\mathrm{a}}$ & .12 & .21 \\
\hline & 3 & .50 & $.38^{\mathrm{a}}$ & .12 & .30 & .27 & $.36^{\mathrm{a}}$ \\
\hline & 2 & $.33^{\mathrm{a}}$ & .37 & .28 & .26 & $.28^{\mathrm{a}}$ & $.27^{\mathrm{a}}$ \\
\hline & 1 & .44 & .55 & $.29^{\mathrm{a}}$ & .22 & .43 & .16 \\
\hline & 0 & .41 & $.45^{\mathrm{a}}$ & .67 & .10 & .22 & .17 \\
\hline & -1 & $.54^{\mathrm{a}}$ & .60 & $.60^{\mathrm{b}}$ & $.38^{\mathrm{a}}$ & $.20^{a}$ & $.27^{\mathrm{a}}$ \\
\hline \multirow[t]{6}{*}{$55-64$} & 4 & .50 & .60 & $.54^{\mathrm{a}}$ & $.09^{\mathrm{a}}$ & .30 & .32 \\
\hline & 3 & .55 & $.54^{\mathrm{a}}$ & .41 & .44 & .36 & $.55^{\mathrm{a}}$ \\
\hline & 2 & $.47^{\mathrm{a}}$ & .62 & .72 & .37 & $.32^{\mathrm{a}}$ & $.40^{\mathrm{a}}$ \\
\hline & 1 & - & - & - & .45 & .50 & .32 \\
\hline & 0 & - & - & - & - & .61 & .33 \\
\hline & -1 & - & - & - & - & $.60^{\mathrm{a}}$ & $.37^{\mathrm{a}}$ \\
\hline \multirow[t]{6}{*}{$55-65$} & 4 & .64 & .75 & $.62^{\mathrm{a}}$ & $.09^{\mathrm{a}}$ & .65 & .48 \\
\hline & 3 & .70 & $.77^{\mathrm{a}}$ & .71 & .59 & .50 & $.64^{\mathrm{a}}$ \\
\hline & 2 & - & - & - & .52 & $.44^{\mathrm{a}}$ & $.47^{\mathrm{a}}$ \\
\hline & 1 & - & - & - & - & .93 & .36 \\
\hline & 0 & - & - & - & - & .83 & .39 \\
\hline & -1 & - & - & - & - & $.73^{\mathrm{a}}$ & $.60^{\mathrm{a}}$ \\
\hline
\end{tabular}

Source: Author's calculations from the NBS.

Note: Based on female-workers sample. Age difference is husband's age minus wife's age. "_" means the probability is not reliably observed.

${ }^{a}$ Based on ten to fifteen observations.

${ }^{b}$ Based on fewer than ten observations. 
of 63. If the husband is four years older than the wife, he would have been 64 or 65 when the wife retired. The joint retirement hypothesis implies that many of these husbands would retire at 64 or 65 , so that few would retire before 63 . The data show that to be the case: just 25 percent of such husbands retired before the age of 63 . Generally, the probability the husband retires should increase in each block as one moves down each column. Similar reasoning implies that, holding constant the difference in age, the retirement probabilities should decrease as the retirement age of the wife increases. An example is the retirement probability at 61 or less of husbands who are the same age as their wives: when the wife retires at 55-59, 41 percent of the husbands retire before 62 ; when the wife retires at 66 or over, just six percent of the husbands retire before 62 .

The entries generally seem to decrease both as the age difference increases and as the wife's retirement age increases. It is desirable, however, to verify this in a systematic way. One method is to calculate the trends in the table. Table 8.7 has the least squares estimates of the trends in the columns. The interpretation of the entries is the change in the husband's retirement probability for a change in the age difference. In the example mentioned before, in which the wife retires at $60-61$, the probability that the husband retires before 63 decreases by .067 for each year of age difference. The average of all the entries in the table is - .033. This is a simple measure of the shift in the retirement distributions for an increase in the age difference. Twenty-one of the thirty entries are negative, which gives additional support to the joint retirement hypothesis. A rough idea of the change in husband's retirement age for a change in age difference can be calculated from the entries in table 8.7. Taking the retirement ages to be the midpoints of each interval (with 67 for the upper interval), one finds that a change of a year in the age difference is associated with an increase in the husband's retirement age of .44 year.

Table 8.8 has the change in the husband's retirement probability for a change in the wife's retirement age, holding constant the age difference. For example, when the age difference is zero, the probability that the husband retires before

Table 8.7

Change in Husband's Retirement Probability for a Change in Age Difference

\begin{tabular}{lrrrrrr}
\hline & \multicolumn{7}{c}{ Wife's Retirement Age } \\
\cline { 2 - 7 } $\begin{array}{l}\text { Husband's } \\
\text { Retirement Age }\end{array}$ & $55-59$ & $60-61$ & 62 & $63-64$ & 65 & $66+$ \\
\hline $55-59$ & .009 & -.042 & .012 & -.010 & -.003 & .005 \\
$55-61$ & -.016 & -.057 & .005 & -.018 & -.017 & .013 \\
$55-62$ & -.021 & -.061 & -.067 & -.036 & -.011 & .011 \\
$55-64$ & .015 & -.010 & -.090 & -.101 & -.069 & .014 \\
$55-65$ & -.060 & -.020 & -.090 & -.215 & -.054 & .007 \\
\hline
\end{tabular}

Source: Calculated from table 8.6.

Note: Based on female-workers sample. 
63 decreases by about .033 for each year the wife delays retirement. The average of the table is -.043 . Twenty-eight of the thirty entries are negative. The increase in husband's retirement age for an increase in wife's retirement age is roughly .47 . Again, these results are consistent with the joint retirement hypothesis.

A simplified summary of what the data reveal about the joint retirement hypothesis is given in table $8.9 .^{2}$ The entries are classified by age difference. They give the percentage distribution of the difference in retirement age. The table aims to show that the difference in age at retirement is systematically

Table 8.8 Change in Husband's Retirement Probability for a Change in Wife's Retirement Age

\begin{tabular}{crrrrr}
\hline & \multicolumn{5}{c}{ Husband's Retirement Age } \\
\cline { 2 - 6 } Age Difference & $55-59$ & $55-61$ & $55-62$ & $55-64$ & $55-65$ \\
\hline 4 & .005 & -.004 & -.024 & -.031 & -.023 \\
3 & -.016 & -.026 & -.016 & -.008 & -.017 \\
2 & -.012 & -.005 & -.008 & -.020 & -.013 \\
1 & -.015 & -.010 & -.027 & -.040 & -.285 \\
0 & -.024 & -.040 & -.033 & -.140 & -.220 \\
-1 & .006 & -.017 & -.038 & -.115 & -.065 \\
\hline
\end{tabular}

Source: Calculated from table 8.6.

Note: Based on female-workers sample.

Table 8.9

Distribution of the Difference in Retirement Age

\begin{tabular}{|c|c|c|c|c|c|c|c|c|c|c|}
\hline \multirow[b]{2}{*}{$\begin{array}{l}\text { Difference in } \\
\text { Retirement Age }\end{array}$} & \multicolumn{10}{|c|}{ Difference in Age } \\
\hline & $\begin{array}{c}-4 \\
\text { to }-2\end{array}$ & -1 & 0 & 1 & 2 & 3 & 4 & 5 & $6-10$ & All \\
\hline-6 to -2 & 43.1 & 17.3 & 15.3 & 10.6 & 12.0 & 10.8 & 5.8 & 14.7 & 10.2 & 14.8 \\
\hline-1 & 9.3 & 24.0 & 9.8 & 5.8 & 1.4 & 2.6 & 6.6 & 6.4 & 6.9 & 7.1 \\
\hline 0 & 10.6 & 15.4 & 25.8 & 14.0 & 7.7 & 6.2 & 7.3 & 2.8 & 5.7 & 10.4 \\
\hline 1 & 6.6 & 10.6 & 11.7 & 28.0 & 18.7 & 5.7 & 5.1 & 5.5 & 6.5 & 11.7 \\
\hline 2 & 4.0 & 4.8 & 9.8 & 10.1 & 23.0 & 14.4 & 9.5 & 6.4 & 5.3 & 10.3 \\
\hline 3 & 11.3 & 5.8 & 6.8 & 6.8 & 12.0 & 23.2 & 14.6 & 10.1 & 5.7 & 10.7 \\
\hline 4 & 5.3 & 1.9 & 4.9 & 5.3 & 6.7 & 10.3 & 29.9 & 14.7 & 6.5 & 9.0 \\
\hline $5-6$ & 4.6 & 11.5 & 9.2 & 9.7 & 10.1 & 12.4 & 11.7 & 26.6 & 22.5 & 13.1 \\
\hline $7-9$ & 5.3 & 8.7 & 6.8 & 9.7 & 8.6 & 14.4 & 9.5 & 12.8 & 30.6 & 12.9 \\
\hline Total Percent & 100.0 & 100.0 & 100.0 & 100.0 & 100.0 & 100.0 & 100.0 & 100.0 & 100.0 & 100.0 \\
\hline \multicolumn{11}{|l|}{ Number of } \\
\hline Observations & 151 & 104 & 163 & 207 & 209 & 194 & 137 & 109 & 245 & 1,519 \\
\hline
\end{tabular}

Source: Author's calculations from the NBS.

Note: Entries are percentage of each column. Difference in age is husband's age minus wife's age. Difference in retirement age is husband's retirement age minus wife's retirement age. Based on combined male- and female-workers samples. 
related to the difference in age. For example, if the joint retirement hypothesis is correct, then husbands and wives who are the same age will tend to retire at the same age; thus, one ought to find that, if the age difference is zero, a high fraction will have the same retirement age. In table 8.9, 25.8 percent of husbands and wives of the same age retired at the same age. Similar reasoning suggests that the largest entries in the table should be along the diagonal: couples with the same difference in age will tend to have the same difference in retirement age. That is exactly what is found in the table: the greatest entry in every column is on the diagonal.

\subsection{Models of Retirement Age}

The results above certainly support the view that retirement dates are correlated, but they give no indication of the source of correlation: joint retirement could be induced by the economic environment, by taste variation, or by complementarity in leisure. For example, it may be that wives and husbands tend to retire at the same time because the wife's Social Security benefit, based on the husband's earnings record, cannot be drawn until the husband retires. One would then find correlation between retirement dates. Further cross-classification by levels of economic resources would allow one roughly to hold constant economic resources, but the counts in the cells would become too small to allow interpretation. A useful way to proceed is to introduce a model of retirement behavior. It will control for economic variables in a way dictated by the functional form. The reader can interpret the results as an extension of the cross-tabulations or as indicative of behavior.

The vehicle for exploring the influence of economic variables on retirement age will be the Stone-Geary utility function. It can quite naturally be parameterized to include both systematic and random taste variations that are econometrically identified. The thought experiment that will lie behind the estimation is as follows: given at age 55 a fixed wage and a stock of assets, workers choose the number of additional years to work. From this point of view, the age of retirement is an object of demand, and an equation that explains the retirement age is a demand equation. Because of the economic environment, however, there are some important differences from the usual kinds of demand estimation; these differences will be discussed below.

Suppose that the husband and wife maximize lifetime utility given by

$$
\left(1-B_{1}-B_{2}\right) \ln (x-a)+B_{1} \ln \left(b_{1}-A_{1}\right)+B_{2} \ln \left(b_{2}-A_{2}\right),
$$

in which $x$ measure lifetime goods consumption; $a$ is a parameter, necessary goods consumption; $A_{1}$ is the husband's years of work (retirement age); $b_{1}$ is the husband's taste parameter; and $A_{2}$ and $b_{2}$ are the wife's years of work and taste parameter. As suggested by the cross-tabulations in section 8.2, $b_{1}$ and $b_{2}$ will depend on the difference in ages and on random components that are 
correlated. In addition, they will vary with health status. For the moment, assume that the lifetime budget constraint is given by

$$
p x=w_{1} A_{1}+w_{2} A_{2}+Y,
$$

in which $p$ is the price of $x, w_{1}$ and $w_{2}$ are the wage rates, and $Y$ is assets. ${ }^{3}$ The retirement equations are

$$
\begin{aligned}
& A_{1}=\left(1-B_{1}\right) b_{1}-B_{1}\left(b_{2} w_{2} / w_{1}+Y / w_{1}-a p / w_{1}\right) \\
& A_{2}=\left(1-B_{2}\right) b_{2}-B_{2}\left(b_{1} w_{1} / w_{2}+Y / w_{2}-a p / w_{2}\right)
\end{aligned}
$$

The taste index of each person enters his own equation and his spouse's equation. Let $b_{1}$ and $b_{2}$ have both systematic parts and random parts as

$$
\begin{aligned}
& b_{1}=X_{1}^{\prime} \beta_{1}+u_{1}, \\
& b_{2}=X_{2}^{\prime} \beta_{2}+u_{2} .
\end{aligned}
$$

On substituting the specifications of $b_{1}$ and $b_{2}$ in the demand equations, the demand equations will have a systematic part that depends on $X_{1}^{\prime} \beta_{1}$ and $X_{2}^{\prime} \beta_{2}$ and error terms (derived from $a_{1}$ and $a_{2}$ ) that have a complicated variancecovariance matrix. From the specification, the structure of the variancecovariance matrix is known, and it offers cross-equation restrictions. With static wages and prices and realizations on $A_{1}$ and $A_{2}$, one could contemplate estimating the parameters, including the taste parameters and variance-covariance matrix.

In the NBS data, a number of obstacles stand in the way of estimation. One observes assets at about the time of retirement, so that the realizations on $Y$ will depend on the realizations on $A$. Neither pensions nor Social Security has been mentioned, yet they surely affect the retirement decision. They have a wealth affect: couples with higher levels of pensions and Social Security will tend to retire earlier. They have price effects: the reward from working another year depends in a complicated way on age, the structure of the pension, the Social Security law, and the contribution history. The price effects act through actuarial reductions in benefits, recalculation of benefits to reflect an extra year's earnings, and within-period effects through the earnings test. Full-scale modeling of the influence of pensions and Social Security on the retirement of a single person is far beyond what can be supported by the NBS because the data give little information on these variables in the years before retirement. For example, even at retirement one does not know the increase in the pension or Social Security that would result from another year of work.

The approach to these problems is to assume that realizations on assets and on annuities (the sum of pensions and Social Security) are representations of the opportunities available to a worker who is contemplating retirement but that the realizations differ from the opportunities by a random component that depends partly on the actual retirement age chosen. This implies that assets and 
annuities should enter equations (1) as endogenous variables. Annuities should have a different coefficient from assets as they are a flow, not a stock.

Weighted averages of the data are shown in table 8.10. The weights account for the stratified sampling procedure. It is evident that there are systematic differences between the two samples. As would be expected, the wives in the female-workers sample have a greater attachment to the labor force than the wives in the male-workers sample: they retire later; they have higher wages and higher Social Security benefits and pensions. They are in better health as a smaller fraction say they have health problems that affect their jobs. The husbands in the female-workers sample are different from the husbands in the male-workers sample: they retire earlier; they have lower wages, fewer assets, smaller Social Security benefits and pensions, and worse health. The health of the husband is a possible reason for the differences between the two samples: the wives of husbands with bad health spent more time in the labor force; the husbands had lower earnings and greater health expenditures, resulting in lower assets at retirement.

The results from estimating the retirement-age equations (1) over the two samples can be found in table 8.11 . The estimates certainly differ across the two samples. This is due at least partly to large standard errors. According to the Stone-Geary utility function, the error terms have heteroscedasticity as well as cross-equation correlation. This was not corrected in the estimation as later results suggest that the Stone-Geary framework may not be appropriate. The emphasis here will be on the average of the two estimates.

Reference to (1) shows that in the husband's retirement equation the vector that explains husband's tastes appears directly, whereas in the wife's equation the vector is multiplied by a factor of proportionality, $-\boldsymbol{B}_{2}$. In the husband's equation, increases in the age difference increase $b_{1}$, which increases the

\begin{tabular}{|c|c|c|c|c|}
\hline & \multicolumn{2}{|c|}{$\begin{array}{l}\text { Male-Workers } \\
\text { Sample }\end{array}$} & \multicolumn{2}{|c|}{$\begin{array}{c}\text { Female-Workers } \\
\text { Sample }\end{array}$} \\
\hline & Husband & Wife & Wife & Husband \\
\hline Retirement age & 63.1 & 58.4 & 61.2 & 62.7 \\
\hline Wage $(\$)$ & 10.91 & 6.65 & 7.68 & 10.42 \\
\hline Assets (\$) & 96,190 & 96,190 & 76,452 & 76,452 \\
\hline \multicolumn{5}{|l|}{ Health limitations: } \\
\hline None & .63 & .55 & .66 & .44 \\
\hline Job & .14 & .14 & .10 & .13 \\
\hline Home & .01 & .01 & .02 & .01 \\
\hline Both & .22 & .30 & .22 & .42 \\
\hline Social Security benefit (annual) (\$) & 6,368 & 2,656 & 4,384 & 5,540 \\
\hline Pension (annual) (\$) & 5,384 & 1,060 & 1,436 & 3,920 \\
\hline
\end{tabular}

Source: Author's calculations from the NBS.

Note: Dollar entries in 1982 dollars. 
Table 8.11

Stone-Geary Model of Retirement Age

\begin{tabular}{|c|c|c|c|c|}
\hline & \multicolumn{2}{|c|}{ Male-Workers Sample } & \multicolumn{2}{|c|}{ Female-Workers Sample } \\
\hline & $\begin{array}{l}\text { Husband } \\
\text { Ret. Age }\end{array}$ & $\begin{array}{l}\text { Wife } \\
\text { Ret. Age }\end{array}$ & $\begin{array}{l}\text { Wife } \\
\text { Ret. Age }\end{array}$ & $\begin{array}{l}\text { Husband } \\
\text { Ret. Age }\end{array}$ \\
\hline \multicolumn{5}{|l|}{ A. Husband's tastes: } \\
\hline Age diff. $\geq 6$ & $1.10^{2}$ & -.02 & .09 & $4.10^{\mathrm{a}}$ \\
\hline $6>$ age diff. $>-4$ & $.16^{\mathrm{a}}$ & -.00 & -.02 & $.35^{\mathrm{a}}$ \\
\hline$-4 \geqslant$ age diff. & .51 & -.47 & -.17 & $-2.35^{\mathrm{a}}$ \\
\hline \multicolumn{5}{|l|}{ Health: } \\
\hline Work & -.48 & .01 & -.08 & -.23 \\
\hline Home & .19 & .09 & .77 & 1.03 \\
\hline Both & $-.60^{\mathrm{a}}$ & -.23 & .04 & $-1.10^{\mathrm{a}}$ \\
\hline \multicolumn{5}{|l|}{ B. Wife's tastes: } \\
\hline Age diff. $\geqslant 6$ & .52 & $-3.90^{\mathrm{a}}$ & -.25 & -.76 \\
\hline $6>$ age diff. $>-4$ & .05 & $-.46^{\mathrm{a}}$ & -.07 & -.05 \\
\hline$-4 \geqslant$ age diff. & -.68 & $3.02^{\mathrm{a}}$ & 1.15 & -1.20 \\
\hline \multicolumn{5}{|l|}{ Health: } \\
\hline Work & .17 & .04 & -.49 & .03 \\
\hline Home & $2.73^{\mathrm{a}}$ & 1.55 & -.61 & .84 \\
\hline Both & $.50^{\mathrm{a}}$ & $-1.19^{\mathrm{a}}$ & -.64 & .34 \\
\hline \multicolumn{5}{|l|}{$\begin{array}{l}\text { C. Economic variables } \\
\text { (all divided by own wage): }\end{array}$} \\
\hline Constant & -2.08 & -.1 .18 & -.56 & -1.29 \\
\hline Spouse wage & -.15 & .22 & .01 & $-.2 \mathrm{l}$ \\
\hline Own annuity (thous. annual $\left({ }^{b}\right)$ & .43 & $5.58^{\mathrm{a}}$ & $.45^{\mathrm{a}}$ & $.92^{\mathrm{a}}$ \\
\hline Spouse annuity (thous. annual) & $.56^{\mathrm{a}}$ & -.14 & .11 & $1.39^{\mathrm{a}}$ \\
\hline Assets (thous.) (b) & -.014 & $-.067^{\mathrm{a}}$ & $-.023^{\mathrm{a}}$ & .013 \\
\hline$R^{2}$ & .06 & .24 & .09 & .27 \\
\hline Observations & 983 & 983 & 702 & 702 \\
\hline
\end{tabular}

Source: Author's calculations from the NBS.

Note: Age diff. = husband age - wife age.

${ }^{a}=|t|>1.96$.

${ }^{\mathrm{b}}$ Endogenous variable.

marginal utility of work and hence increases the retirement age. ${ }^{4}$ The average of the effects in the two samples is about .26 per year of age difference: increasing the age difference by a year would increase the husband's retirement age by .26 year, holding constant the wife's taste parameter. If the factor of proportionality in the wife's equation is negative, which it should be, one finds the same pattern of signs on the age difference variables as in the husband's equations.

The husband's own health affects his retirement age in the expected way. It is interesting that the few husbands who say that health limits their work at home tend to retire later. In the wife's retirement equation, the same negative factor of proportionality that multiplies husband's health should multiply the age difference, yet there is little consistency of sign. 
In the wife's retirement-age equation, the wife's taste index decreases in the age difference, which is symmetric with the husband's taste index. Thus, if the age difference decreases (the wife becomes older), the marginal utility of work of the wife increases, and she retires later, just as does the husband if his age increases. On average, a decrease of a year in the age difference increases the wife's retirement age by .27 year, holding constant the husband's taste index. The responses of the husband and wife are for practical purposes exactly the same. The effect of age difference on the wife's taste index in the husband's retirement equation should, at least, have the same sign over the two samples, but there is no such consistency.

In the wife's retirement equation, the wife's health indicators affect retirement in the usual way: if health affects work on the job, $b_{2}$ decreases, and the wife retires earlier. In the husband's equation, bad health increases the husband's retirement age. The effect is through $b_{2}$, which, if the factor of proportionality is negative, decreases with bad health. This reduces the wife's retirement age and increases the husband's.

The total effects of the economic variables cannot be read directly from the table because of interactions. As far as the own wage is concerned, it has a positive effect if all the other economic variables with which it is interacted are put to zero. However, if they are evaluated at their sample means, the wage effect takes the opposite sign: evaluating own wage, spouse wage, own annuity, spouse annuity, and assets at the sample means produces these estimates of the wage effects in years per dollar (see table 8.12). Thus, increasing the own wage tends to cause earlier retirement, although the change is not large.

The spouse's wage is interacted with the spouse's taste vector and with the own wage. Evaluated at no health limitation and no age difference, the average effect (over both samples) of the wife's wage on the husband's retirement is about -.02 year per dollar; the effect of the husband's wage on the wife's retirement is about .02 year per dollar. These effects are practically zero.

The effect of own annuity (the sum of Social Security and pensions) on retirement age averages about .04 year per thousand for husbands and .43 for wives. Both suggest that the price effect dominates income effects: apparently, the annuity gain from delaying retirement is substantial.

The effect of the husband's annuity on the wife's retirement age is practically zero. An increase in the wife's annuity on the husband's retirement age is positive and of moderate magnitude. An explanation for this is found

Table 8.12

Effect of Own Wage on Own Retirement Age

\begin{tabular}{lcc}
\hline & $\begin{array}{c}\text { Husband's } \\
\text { Retirement }\end{array}$ & $\begin{array}{c}\text { Wife's } \\
\text { Retirement }\end{array}$ \\
\hline Male Data & -.02 & -.31 \\
Female Data & -.14 & -.02 \\
\hline
\end{tabular}


in the wife's response to her own annuity: her retirement age increases, so the husband's retirement age also increases.

The average effect of assets on the husband's retirement age is practically zero. The average change in the wife's retirement age is about -.006 year per thousand dollars of assets. Because these data have considerable variation in assets across households, asset variation can reduce the wife's retirement age by several years.

Table 8.13 summarizes the effects of the economic variables. Part A gives the estimated change in retirement age associated with changing the economic variables from the twenty-fifth percentile point in the distribution of the variable to the seventy-fifth percentile point. Part B gives the changes in the variables that underlie the calculations. For example, a change of $\$ 5.2$ thousand in the wife's annuity is estimated to increase the wife's retirement age by 2.24 years.

One might well ask whether the Stone-Geary utility function produces a reasonable representation of the data. The response of retirement age to the economic variables certainly seems reasonable, but this is not really a test of the functional form. The utility function implies a number of cross-equation restrictions that were not imposed in the estimation. They result from the appearance of both taste parameters in both retirement equations. The factor of proportionality is $-B_{2} /\left(1-B_{1}\right)$ for the husband's index and $-B_{1} /\left(1-B_{2}\right)$ for the wife's index, and $-B_{1}$ and $-B_{2}$ are the coefficients on assets. But it would be taking the model beyond reasonable bounds to estimate $B_{1}$ and $B_{2}$ from the coefficients on assets for the purpose of checking the equivalence of the index parameters because of other implicit factors. For example, wage rates are in dollars per hour, whereas the utility function refers to lifetime utility. A more generous test of the proportionality hypothesis rests on whether the $12 \times 4$ matrix

$$
\hat{B}=\left(\hat{\beta}_{1} \hat{\beta}_{2} \hat{\beta}_{3} \hat{\beta}_{4}\right)
$$

has rank one. Each of the $\hat{\beta}$ is a twelve-vector of the estimated coefficients that give the husband's and wife's taste parameters. Each retirement equation produces two estimates of the $\hat{\beta}$, one from each data set. The form of the test comes from noting that one should be able to write each vector as

Table 8.13

\begin{tabular}{|c|c|c|c|c|c|}
\hline & Own Wage & Spouse Wage & Own Annuity & Spouse Annuity & Assets \\
\hline \multicolumn{6}{|c|}{ A. Changes in retirement age: } \\
\hline Husband & -.52 & -.08 & .32 & .47 & .00 \\
\hline Wife & -.61 & .10 & 2.24 & .00 & -.40 \\
\hline \multicolumn{6}{|c|}{ B. Changes in variables: } \\
\hline Husband & 6.5 & 3.8 & 8.0 & 5.2 & 67 \\
\hline Wife & 3.8 & 6.5 & 5.2 & 8.0 & 67 \\
\hline
\end{tabular}




$$
\beta_{i}=k_{i} \beta,
$$

where $k_{\mathrm{i}}$ is a scalar. This implies that $B$ has rank one. The normalized characteristic roots of $\hat{B}^{\prime} \hat{B}$ are

$$
.45, .32, .17, .06 \text {. }
$$

The second and third are far enough from zero that a formal test was not conducted, and $\hat{B}$ was concluded to have rank greater than one.

The retirement equations derived from the Stone-Geary utility function are complicated and difficult to interpret because of the interactions. In that the cross-equation restrictions do not seem to hold, a simplified retirement equation was estimated. Retirement was made linear in all the variables. The results of that estimation are in table 8.14. As before, the estimation method is instrumental variables taking own annuity and assets to be endogenous variables.

As far as the effects of own taste variables on own retirement age are concerned, they are about the same as the average effects from the Stone-Geary formulation. Both formulations produce an increase in retirement age of husbands of about .25 per year of age difference and .27 for wives. The effects

Table 8.14

\begin{tabular}{|c|c|c|c|c|}
\hline & \multicolumn{2}{|c|}{ Male-Workers Sample } & \multicolumn{2}{|c|}{ Female-Workers Sample } \\
\hline & $\begin{array}{l}\text { Husband } \\
\text { Ret. Age }\end{array}$ & $\begin{array}{c}\text { Wife } \\
\text { Ret. Age }\end{array}$ & $\begin{array}{c}\text { Wife } \\
\text { Ret. Age }\end{array}$ & $\begin{array}{l}\text { Husband } \\
\text { Ret. Age }\end{array}$ \\
\hline Age diff. $\geqslant 6$ & $1.46^{\mathrm{a}}$ & $-3.88^{\mathrm{a}}$ & -.08 & $3.65^{\mathrm{a}}$ \\
\hline $6>$ age diff. $>-4$ & $.19^{a}$ & $-.47^{\mathrm{a}}$ & -.08 & $.31^{\mathrm{a}}$ \\
\hline$-4 \geqslant$ age diff. & .04 & $2.37^{\mathrm{a}}$ & 1.13 & $-3.16^{\mathrm{a}}$ \\
\hline \multicolumn{5}{|l|}{ Own health: } \\
\hline Work & -.42 & .10 & -.36 & -.16 \\
\hline Home & .42 & 1.15 & -.60 & .69 \\
\hline Both & -.37 & $-1.52^{\mathrm{a}}$ & $-.68^{\mathrm{a}}$ & $-1.14^{\mathrm{a}}$ \\
\hline \multicolumn{5}{|l|}{ Spouse health: } \\
\hline Work & $.80^{\mathrm{a}}$ & -.18 & .50 & -.01 \\
\hline Home & .81 & .75 & .28 & .49 \\
\hline Both & .38 & -.28 & .20 & .31 \\
\hline Own wage & -.00 & -.04 & -.01 & -.04 \\
\hline Spouse wage & -.01 & .03 & -.00 & -.01 \\
\hline Own annuity (thous. annual) (b) & -.056 & $.615^{\mathrm{a}}$ & $.415^{\mathrm{a}}$ & -.047 \\
\hline Spouse annuity (thous. annual) & $.064^{\mathrm{a}}$ & -.037 & .006 & $.106^{\mathrm{a}}$ \\
\hline Assets (thousands) (b) & .006 & -.011 & $-.021^{\mathrm{a}}$ & .007 \\
\hline Observations & 983 & 983 & 702 & 702 \\
\hline$R^{2}$ & .06 & .21 & .09 & .23 \\
\hline
\end{tabular}

Simplified Model of Retirement Age

Source: Author's calculations from the NBS.

Note: Age diff. = husband age - wife age.

$\mathrm{a}=|t|>1.96$.

bendogenous Variable. 
of the own health variables on own retirement age are given in table 8.15. The effects are remarkably consistent across estimation methods, and they are very similar for husbands and wives. There is, of course, some question about the interpretation of these effects: they are based on the reported health status after retirement. They will be the result of a mixture of people who become seriously ill so that they cannot work, people who may have a chronic minor illness so that they choose not to work, and a range of people in between. Although only 1-2 percent of the individuals report their health affects work at home, they work about a half a year longer than people with no such health limitation.

The effects of the economic variables can be most easily summarized by giving the change in retirement age that would result from changing a variable from the twenty-fifth percentile to the seventy-fifth. The changes in retirement age are given in table 8.16. The own wage response is practically zero here, whereas in the Stone-Geary formulation it was about -.5 year. Other differences are that in these results an increase in own annuities causes the husband to retire earlier, whereas in the Stone-Geary results he retired later. The wife's response to assets is almost three times as great as before.

The correlation between the residuals from the husband's and wife's retirement equation is .29 in the male data and .32 in the female data. Thus, even taking into account the age differences and the spouse's economic variables, there still remains unexplained positive correlation between the retirement ages.

If someone desires to work beyond the normal retirement age associated with his primary job, often he must change jobs, and often the new job has a lower wage rate than the primary job (Burtless and Moffitt 1985; Gustman and Steinmeier 1986). One would, therefore, tend to find a negative association between the wage and the retirement age. Put differently, the wage on the last job depends on the retirement age, so that, according to this reasoning, it is endogenous in a retirement equation. To check the empirical importance of this observation, the simplified retirement equation of table 8.14 was reestimated taking the own wage as well as assets and own annuity to be endogenous. The

Table 8.15 Effect of Own Health on Own Retirement

\begin{tabular}{lrrrrr}
\hline & \multicolumn{2}{c}{ Husbands } & & \multicolumn{2}{c}{ Wives } \\
\cline { 2 - 3 } & Stone-Geary & Simple & & Stone-Geary & Simple \\
\hline Job & -.35 & -.29 & & -.22 & -.13 \\
Home & .60 & .56 & & .47 & .28 \\
Both & -.85 & -.76 & -.92 & -1.10 \\
\hline
\end{tabular}

Table 8.16

\begin{tabular}{lccccr}
\hline & Own Wage & Spouse Wage & Own Annuity & Spouse Annuity & Assets \\
\hline Husband & -.13 & -.04 & -.41 & .44 & .40 \\
Wife & -.10 & .10 & 2.68 & -.12 & -1.07 \\
\hline
\end{tabular}


results are very similar to those in table 8.14 , so they are not reported. Of particular interest is that the own wage response remains small.

A further method to find the interaction between retirement ages is to estimate a conditional retirement equation. It specifies that the retirement age of, say, the husband depends on the retirement age of the wife. From such an equation one can directly read the magnitude of the dependence. The theoretical justification is based on the conditional distribution of bivariate normal random variables. If $X$ and $Y$ are bivariate normal random variables, then

$$
E(Y \mid X)=\mu_{y}+\rho \frac{\sigma_{y}}{\sigma_{x}}\left(X-\mu_{x}\right)
$$

in which $\mu_{y}$ is $E(Y) ; \mu_{x}$ is $E(X) ; \rho$ is the correlation coefficient between $Y$ and $X$; and $\sigma_{y}$ and $\sigma_{x}$ are the standard errors of $Y$ and $X$. Let $Y$ be the retirement age of the husband and $X$ be the retirement age of the wife. Then the coefficient on the retirement age of the wife in the husband's retirement equation should be $\rho \sigma_{y} / \sigma_{x}$.

Table 8.17 has the estimated conditional retirement equations. The functional form is the simplified retirement equation of table 8.14 with the addition that the spouse's retirement age enters as a right-hand variable. The estimated coefficients are qualitatively similar to those reported in table 8.14 , so they will not be discussed further. Of greater interest is that the spouse's retirement age is an important explanatory variable. Increasing the wife's retirement age by a year increases the husband's retirement age by about .25 year (average over both data sets); increasing the husband's retirement age by a year increases the wife's retirement age by about .37 year. As discussed earlier, a rough estimate of the effect of the wife's retirement age on the husband's retirement age can be found from the results in table 8.8. That effect is .47. Given the great difference in methods, this compares rather well with the estimate in table 8.17. These relations between retirement ages are in addition to any induced by the age difference, which by itself would tend to cause retirement dates to be correlated.

The conditional retirement results may be compared with unconditional results by using the theory of normal random variables. As discussed above, the coefficient on $X$ in the relation $E(Y \mid X)$ should be $\rho \sigma_{y} / \sigma_{x}$. $\rho$ was estimated to be $.24, \sigma_{y}$ to be 2.71 , and $\sigma_{x}$ to be 4.15 over the male workers data in unconditional estimation of the retirement ages in the simplified model with endogenous assets, own annuity and own wage. ${ }^{5}$ Thus, the coefficient on $X$, the wife's retirement age in the conditional equation for the husband's retirement age, should be $.24 \times 2.71 / 4.15=.16$. The actual value from table 8.17 is .18 . Table 8.18 summarizes the comparisons.

The comparisons are quite close and support further the joint retirement hypothesis. The general impression is that the husband's retirement age has a greater effect on the wife's retirement age than the wife's on the husband's. This accords with the generally accepted view in the labor supply literature. 
Table 8.17

Determinants of Conditional Retirement Age

\begin{tabular}{|c|c|c|c|c|}
\hline & \multicolumn{2}{|c|}{ Male-Workers Sample } & \multicolumn{2}{|c|}{ Female-Workers Sample } \\
\hline & $\begin{array}{l}\text { Husband } \\
\text { Ret. Age }\end{array}$ & $\begin{array}{c}\text { Wife } \\
\text { Ret. Age }\end{array}$ & $\begin{array}{c}\text { Wife } \\
\text { Ret. Age }\end{array}$ & $\begin{array}{l}\text { Husband } \\
\text { Ret. Age }\end{array}$ \\
\hline Age diff. $\geqslant 6$ & $1.98^{\mathrm{a}}$ & $-2.13^{\mathrm{a}}$ & $-1.36^{\mathrm{a}}$ & $3.68^{\mathrm{a}}$ \\
\hline $6>$ age diff. $>-4$ & $.26^{\mathrm{a}}$ & $-.30^{\mathrm{a}}$ & -.09 & $.31^{\mathrm{a}}$ \\
\hline$-4 \geqslant$ age diff & -.41 & $2.27^{\mathrm{a}}$ & $1.65^{\mathrm{a}}$ & $-3.39^{\mathrm{a}}$ \\
\hline \multicolumn{5}{|l|}{ Own health: } \\
\hline Work & -.45 & -.11 & -.19 & -.22 \\
\hline Home & .17 & 1.02 & -1.24 & .75 \\
\hline Both & -.43 & $-1.57^{\mathrm{a}}$ & $-.85^{\mathrm{a}}$ & $-1.10^{\mathrm{a}}$ \\
\hline \multicolumn{5}{|l|}{ Spouse health: } \\
\hline Work & $.69^{\mathrm{a}}$ & -.09 & .47 & -.29 \\
\hline Home & 1.07 & .76 & -.24 & .37 \\
\hline Both & $.57^{\mathrm{a}}$ & -.08 & .37 & .47 \\
\hline Own wage $\left({ }^{b}\right)$ & -.02 & -.05 & -.01 & -.01 \\
\hline Spouse wage & .00 & .03 & -.02 & -.01 \\
\hline Own annuity (thous. annual) ( ${ }^{b}$ ) & .007 & $.801^{a}$ & $.546^{\mathrm{a}}$ & .038 \\
\hline Spouse annuity (thous. annual) & -.001 & -.049 & .017 & -.004 \\
\hline Assets (thousands) ${ }^{b}$ ) & .003 & -.012 & $-.033^{\mathrm{a}}$ & .007 \\
\hline Spouse retirement age & $.18^{\mathrm{a}}$ & $.38^{\mathrm{a}}$ & $.36^{\mathrm{a}}$ & $.33^{a}$ \\
\hline Observations & 983 & 983 & 702 & 702 \\
\hline$R^{2}$ & .12 & .26 & .14 & .30 \\
\hline
\end{tabular}

Source: Author's calculations from the NBS.

Note: Age diff. = husband age - wife age.

${ }^{a}=|t|>1.96$.

${ }^{\mathrm{b}}$ Endogenous variable.

Table 8.18

\begin{tabular}{lcc}
\hline & \multicolumn{2}{c}{$\begin{array}{c}\text { Effect of Wife's Retirement Age } \\
\text { on Husband's Retirement Age }\end{array}$} \\
\cline { 2 - 3 } Data Set & $\begin{array}{l}\text { Directly Estimated } \\
\text { (table } 8.17)\end{array}$ & From Normal Theory \\
\hline Male workers & .18 & .16 \\
Female workers & .33 & .19 \\
\cline { 2 - 3 } & \multicolumn{2}{c}{$\begin{array}{c}\text { Effect of Husband's Retirement Age } \\
\text { on Wife's Retirement Age }\end{array}$} \\
\cline { 2 - 3 } Male workers & $\begin{array}{c}\text { Directly Estimated } \\
\text { (table } 8.17)\end{array}$ \\
\cline { 2 - 3 } Female workers & .38 & .37 \\
\hline
\end{tabular}




\subsection{Conclusion}

The results support the idea that the retirement of husbands and wives is a joint process. Often both spouses retire within a short period. The difference in age seems to cause substantial variation in retirement age. The rough estimate from the retirement probabilities is about .45 year per year of age difference. From either the Stone-Geary or the simple model, it is about .25 . Given the wide differences in estimation methods, these estimates are in good agreement and certainly support the joint retirement hypothesis.

Generally, the cross-economic variables do not have a strong effect on retirement ages, so they do not provide a good explanation for the correlation of retirement dates. But it would be surprising to have strong cross-effects given that the own effects are not strong. Surely, this is at least partly due to weaknesses in the data and to the simplified estimation methods required by the data. In particular, one cannot construct the economic environment in the years before retirement.

The residual correlation between the retirement ages of husbands and wives also supports the joint retirement hypothesis. Of course, one does not know the cause of the correlation: it could be due to neglected economic variables, assortative mating, or true complementarity in the utility function.

Much more research on the joint retirement decision is needed. In particular, a close modeling of Social Security and pensions should be able to separate the wealth effects from the price effects. Nothing was done here about adjustment of hours within a year, which is often accompanied by a reduction in the wage rate. One would hope that future research would be able to account for these problems and to find the extent of true complementarity in retirement.

\section{Notes}

1. Henretta and O'Rand (1983) find in the RHS that increasing the age of the wife decreases the probability that she will retire after the husband, which seems to imply a correlation. But this result cannot be interpreted as a joint retirement decision: one would get the same result if individuals in the sample were randomly attached to other individuals simply because increasing age is associated with decreased labor force participation.

2. This table was suggested by David Ellwood.

3. The model does not have a role for the adjustment of annual hours of work. In this formulation, the wage is implicitly the annual wage (earnings); but in the estimation the hourly wage is used as it is surely a better measure of the cost of leisure.

4. The dependence of tastes on the age difference was, in estimation not reported here, represented by ten dummy variables; the relation was close enough to linear that tastes were made linear in age differences between minus four and six.

5. This correlation is slightly different from what was reported earlier because it comes from an equation in which the own wage is endogenous. 


\section{References}

Boskin, M., and M. Hurd. 1978. The effect of Social Security on early retirement. Journal of Public Economics 10 (December):361-77.

Burkhauser, R. 1980. The early acceptance of Social Security-an asset maximization approach. Industrial and Labor Relations Review 33 (4):484-92.

Burtless, G., and R. Moffitt. 1985. The joint choice of retirement age and postretirement hours of work. Journal of Labor Economics 3:209-36.

Diamond, P., and J. Hausman. 1984. Individual retirement and savings behavior. Journal of Public Economics 23:81-114.

Gustman, A., and T. Steinmeier. 1986. A structural retirement model. Econometrica $54(3): 555-84$.

Hausman, J., and D. Wise. 1985. Social Security, health status and retirement. In Pensions, labor, and individual choice, ed. D. Wise. Chicago: University of Chicago Press for the NBER.

Henretta, J., and A. O'Rand. 1983. Joint retirement in the dual worker family. Social Forces 62 (December):504-20.

Honig, M., and G. Hanoch. 1985. Partial retirement as a separate mode of retirement behavior. Journal of Human Resources 20 (Winter):21-46.

Hurd, M., and M. Boskin. 1984. The effect of Social Security on retirement in the early 1970's. Quarterly Journal of Economics (November):767-90.

Maxfield, L. 1983. The 1982 new beneficiary survey: An introduction. Social Security Bulletin 46 (11).

Mitchell, O., and G. Fields. 1983. Economic incentives to retire: A qualitative choice approach. NBER Working Paper no. 1128. Cambridge, Mass.: National Bureau of Economic Research.

1984. The economics of retirement behavior. Journal of Labor Economics 2 (January):84-105.

Pozzebon, S., and O. Mitchell. 1989. Married women's retirement behavior. Journal of Population Economics 2(1): 39-53.

Sickles, R., and R. Taubman. 1986. An analysis of the health and retirement status of the elderly. Econometrica 54 (November):1339-56.

\section{Comment Gary Burtless}

Michael Hurd's paper has two main goals. The author would like to provide good baseline information about the presence and magnitude of correlated retirement dates among working spouses. Do working spouses tend to retire on or around the same day? How large is the correlation? The second goal is to determine whether and how much economic variables contribute to the correlation in retirement dates. Is the correlation in retirement more or less than would be expected given the correlation in other variables that affect each spouse's retirement age? When describing his latter goal, Hurd prudently adds D.C.

Gary Burtless is a senior fellow in economic studies at the Brookings Institution, Washington, 
that he will try to establish the facts "within the constraints of the data." As we shall see below, the constraints imposed by the data are severe.

The author mentions three reasons to expect some correlation in retirement dates: $(a)$ sorting of marital partners by tastes, so that men and women who like to work or shirk seek out and wed a similarly inclined spouse; $(b)$ effects of economic variables, such as asset income, that are shared by both spouses and affect the behavior of each; and (c) simultaneous determination of the utility each spouse derives from retirement. A retired worker who has a working spouse may enjoy less utility - at the same income level-than the same worker would obtain if his or her spouse were retired.

The first two reasons for correlation in retirement do not cause serious problems for the separate estimation of the retirement equations of husbands and wives. If there is a correlation in taste for work among marriage partners, for example, no special problems arise in estimation. In estimating an equation that explains husbands' retirement age, it is interesting and useful to learn that a correlation exists in the retirement ages of the two spouses. We could improve the efficiency of the unknown parameters in the retirement equation if the correlation in the error terms were taken into account. But, if the correlation in errors is ignored, there seems no reason to believe that the parameter estimates would be biased.

Similarly, in a static retirement model it would sometimes be useful to know that retirement ages of husbands and wives are correlated because both spouses face similar environmental factors. But, when the analyst has no particular interest in this correlation, nothing is lost if it is ignored. ${ }^{1}$ The simplest estimation strategy is to include the wage of both spouses, the health status of both spouses, and the pension incentives facing each spouse in the separate equations for each spouse.

The third issue seems to me much more difficult to handle. Suppose we were given a data set with good information on retirement ages and the economic, health, and demographic determinants of retirement. If husbands and wives tend to retire on the same calendar date, irrespective of the other determinants of their individual retirement ages, this fact may have to be explicitly taken into account if the analyst wants to obtain unbiased estimates of the other coefficients in the system. The retirement age of the wife may be influenced, not only by the exogenous determinants of her husband's retirement age, but also by the actual realization of that age. How important is the bias that follows from ignoring this correlation? Before reading this paper, I would have thought that the potential bias is small.

This set of issues is examined using the New Beneficiary Survey (NBS), a survey of workers who began collecting Social Security old age insurance (OAI) benefits between June 1980 and May 1981. The sample is explicitly selected on the basis of the retirement or benefit acceptance choice of respondents.

The choice-based nature of the selection process introduces serious problems in estimation, as Hurd clearly demonstrates in the paper. For example, 
if we consider the subsample of 62-year-old men, we note two types of sample exclusions that affect the representativeness of the remaining sample. First, the survey excludes those workers who have already retired and accepted Social Security disability insurance (DI) benefits. And it excludes 62-year-old men who will accept their OAI pension at a later age. If we are interested only in the retirement behavior of nondisabled men, the first exclusion is not very troubling. But the second exclusion-of nonretired 62-year-olds-is extremely serious. The NBS sample systematically excludes information on 62-year-olds who have greater taste for work and who have independent variables associated with above-average retirement ages. This exclusion will clearly bias any inference we want to draw about the retirement behavior of all nondisabled 62-year-old men.

As Hurd points out, the effects of the sample exclusion can be overcome under certain assumptions, in particular, under the assumption that the economic and demographic determinants of retirement are constant across time and across age cohorts. Although we are missing data on 62-year-olds who wish to retire later than average, we possess data on 65 - and 70-year-olds who do retire later than average. If the population is static, the data set contains information on a good cross section of individual tastes and economic and demographic determinants of retirement.

In a sample as aged as this one, however, it may not be plausible to assume that population conditions are static. Mortality rates, especially among men, are quite high between ages 62 and 72. Some 62-year-old workaholics will never survive long enough to accept a Social Security pension. These are the hard drivers who work until they drop-or at least they drop sometime before age 72 when they would be mailed a check even without retiring. You always resented these characters in high school and college-unless you were one yourself. They messed up the grading curve in school, and now they screw up our econometric models by denying us deathbed information on critical $X$-variables.

In addition, Hurd points out that it would be dangerous to assume that the population is static, anyway. Economic variables - such as the wage- are not constant across successive cohorts. To take a simple example, if the wage is higher in each cohort, workers retiring at age 70 could have a worse earnings record than workers retiring at age 62 . Even if the wage has no effect on retirement, the analyst using this data set might incorrectly conclude that low wages lead to later retirements.

Hurd might also have mentioned a further economic factor, one that seems especially significant in light of his views on the effects of Social Security on early retirement. The younger retirees in the NSB sample were affected by the most dramatic benefit cut in social security history. Those of you who read Dear Abby will know what I am talking about: the notorious Social Security "notch babies." They are not exactly spring chickens today, of course, since they turned 65 between 1982 and 1986. But these folks were hit by major 
benefit cuts as a result of the Social Security amendments passed in 1977, which became effective in 1979. About half Hurd's sample was born just before the notch took effect, while the remaining half had the bad luck to be born just after.

You might think this issue is relevant only to cranks who write Dear Abby or who badger hapless congressmen in Washington. To allay these suspicions, let me report a couple of numbers.

- If you were an average-wage worker, had worked steadily throughout your career, and turned 65 on 31 December 1981, you would have received a Social Security check on 1 January 1982 equal to 51 percent of your last month's earnings in December.

- If you had an identical earnings record but the great misfortune to turn 65 on 2 January 1982, your 1 February 1982 Social Security check would have been just 41 percent of your December wage earnings.

In other words, the benefit replacement rate dropped from 51 to 41 percent at midnight, 1 January 1982. For you who are a little slow at arithmetic, that is a 20 percent drop in real benefits for the identical earnings record.

Not only did notch babies receive sharply lower benefits if they retired at age 65 , but they also obtained much smaller benefit increments if they delayed retirement for additional years.

Boskin and Hurd (1978) found that the benefit increase in 1972-73 had a major effect on retirement patterns after 1972. (That conclusion is repeated near the beginning of this paper.) I would expect equally dramatic effects of the benefit cut passed in 1977. Do we see any delay in retirement among "notch babies"?

Interesting though this question is, Hurd does not directly address it in this paper. Rather, he wants to know whether there is a correlation between the retirement dates chosen by husbands and wives. How important is this correlation? The evidence in the paper suggests that the issue merits some attention.

In his first set of tabulations, Hurd finds that there is some tendency for husbands and wives to retire near the same calendar date. Partly, this is because the husbands and wives he looks at tend to have similar calendar ages and because he excludes from his comparisons those couples who retire at widely different ages. Within the sample of couples he looks at, however, there appears to be some clustering of retirement dates.

The cross-tabulations used to draw this inference are based on a relatively small proportion of the observations in the NBS. One of the reasons is that families are excluded if either husband or wife stopped working by age 54 . Another reason is that retirement ages were required for both husbands and wives-so, if the spouse of the new beneficiary had not yet retired by the interview date, the observation was excluded. Both these criteria will tend to exclude couples with wide differences in retirement ages and, presumably, in retirement dates. 
Nonetheless, Hurd's conclusion appears to be borne out using a variety of different analytic techniques and number of cross-classification schemes. In the concluding section of the paper, Hurd presents estimates of a reduced-form joint retirement equation, one that links information about both husbands and wives in estimating the separate retirement behavior of the two spouses. Given the limitations of his data set, the exact coefficient estimates should probably be viewed with some skepticism.

Even taking account of all the statistical problems with the estimation procedures, however, it is still reasonable to conclude, as Hurd does, that the correlations in the data support his basic inference: for many couples in the sample, retirement is a jointly determined process. Only a fraction of the correlation in retirement dates is explained by the observable economic variables that affect both members of a married couple.

Having satisfied ourselves that Hurd's inference is a reasonable one, how should we alter the statistical methods typically used to estimate retirement models? In certain kinds of models, it is feasible to account explicitly for the correlation of husband and wife retirement dates. Where this is feasible, it certainly should be done. For many models, however, it would be extremely difficult, if not impossible, to control statistically for the correlation between retirement dates of husbands and wives. The results in this paper, while suggestive, do not seem strong enough to require us to toss out the findings obtained from the latter type of model.

\section{Note}

1. For example, most analysts have been interested in the effects of Social Security, private pensions, or health on retirement ages. If the specification of these factors in the individual retirement equations is correct, no explicit account need be taken of the correlation in spouses' retirement ages arising from the correlation in their environmental factors.

\section{Reference}

Boskin, M., and M. Hurd. 1978. The effect of Social Security on early retirement. Journal of Public Economics 10 (December):361-77. 